\title{
Terapi Aktivasi Perilaku dapat mengurangi simtom anhedonia pasien skizofrenia?
}

\author{
Tri Wiganti Andayani ${ }^{1}$ dan Uun Zulfiana ${ }^{2}$
}

\begin{abstract}
The goal of the intervention is to reduce the negative symptoms of people with schizophrenia. The assessments used were interviews, observations, and psychological tests which included graphic tests (BAUM, DAP, HTP), WAIS, and SSCT. The client's problem is that he loses the pleasure of doing daily activities that used to be fun or made him happy. The intervention uses Behavioral Activation Therapy by providing a daily activity schedule. The results of the intervention show a decrease in symptoms of anhedonia, marked by an increase in daily client activities including bathing twice a day, being on time in taking medication, praying and helping with homework
\end{abstract}

\section{Keywords}

Behavioral activation, schizophrenia, negative symptoms

\section{Pendahuluan}

Skizofrenia merupakan gangguan dengan serangkaian simptom yang dibagi menjadi 3 dimensi yaitu: simptom positif mencakup hal-hal yang berlebihan dan distorsi, seperti halusinasi dan waham. simptom negatif mencakup berbagai defisit behavioral yang merupakan prediktor kuat terhadap kualitas hidup yang rendah, seperti avolition, alogia, anhedonia, afek datar, dan asosialitas. simptom disorganisasi mencakup disorganisasi pembicaraan dan perilaku aneh (Oltmanns \& Emery, 2013). Seseorang didiagnosa skizofrenia apabila mengalami sedikitnya dua dari gejala tersebut dalam kurun waktu 6 bulan, sehingga menyebabkan keberfungsian sosial dan pekerjaan menurun sejak gangguan terjadi (American Psychiatric Association, 2005).

Beberapa perilaku pada skizofrenia sangat beragam, salah satunya yang menonjol adalah suatu keadaan dimana seseorang tidak mendapat kesenangan dari melakukan aktivitas-aktivitas yang dulunya menyenangkan atau membuatnya bahagia (anhedonia), yang merupakan salah satu simptom negatif pada skizofrenia. Perilaku ini ditunjukkan dengan gejala seperti malas, apatis, tidak punya keinginan, seharian hanya tidur, melamun sepanjang hari (Oltmanns \& Emery, 2013; Davidson et al., 2012).

Kurangnya klien dalam melakukan aktivitas seharihari sehingga menyebabkan badan klien terasa capek karena tidur seharian. Klien merupakan pasien skizofrenia yang telah dipulangkan dan selesai menjalani perawatan di Yayasan Dian Atmajaya Lawang. Klien terdiagnosa skizofrenia sejak usia 18 tahun pada tahun 2015, dan telah mengalami 4 kali relaps. Klien berulang kali mengalami relaps karena keberfungsian di lingkungannya berkurang, klien menilai dirinya tidak berguna sehingga klien rentan terhadap stres dan relaps. Aspek yang paling penting dan benar-benar melemahkan penyakit skizofrenia adalah malfungsinya hubungan interpersonal (Oltmanns \& Emery, 2013).

Klien juga tidak memiliki aktivitas harian yang bermanfaat untuk dilakukan di rumah sehari-hari setelah pulang dari perawatan di Yayasan Dian Atmajaya Lawang. Kurangnya aktivitas pada klien dan hilangnya kemauan dalam mengelola diri mengakibatkan klien mengembangkan perilaku yang buruk, seperti mandi tidak teratur, hanya tidur-tiduran sepanjang hari, malas menjalankan aktivitas sehingga badan terasa capek, lemas seperti tidak punya tenaga, juga tidak ada interaksi di lingkungan sosialnya baik dengan keluarga, tetangga disekitar rumahnya. Hal ini menunjukkan kurangnya kemauan klien dalam melakukan aktivitas menyenangkan (anhedonia) yaitu suatu keadaan dimana seseorang tidak mendapat kesenangan dari melakukan aktivitas yang dulunya menyenangkan atau membuatnya bahagia. Perilaku ini menjadi penting karena dapat membuat malfungsinya hubungan interpersonal pada orang dengan gangguan skizofrenia (Oltmanns \& Emery, 2013). Berdasarkan permasalahan di atas maka, intervensi yang sesuai dalam mengatasi permasalahan klien adalah terapi aktivasi perilaku.

\footnotetext{
1,2Universitas Muhammadiyah Malang
}

Korespondensi:

Tri Wiganti Andayani, Direktorat Program Pascasarjana, Universitas Muhammadiyah Malang, Jl. Tlogomas 246 Malang, Indonesia

Email: triwigantiandayani@gmail.com 
Terapi aktivasi perilaku dalam beberapa penelitian sebelumnya ditemukan sebagai salah satu teknik yang efektif, sederhana dalam masalah yang berkaitan dengan hilangnya motivasi dan suasana hati, juga mengurangi simptom negatif pada skizofrenia, serta untuk mengurangi gejala pada pasien depresi (Cuijpers et al., 2007; Hopko et al., 2011; Mairs et al., 2011; Scholten, 2006). Terapi aktivasi perilaku dapat berupaya mengatasi perilaku negatif dan membantu mengurangi simptom negatif dan efektif untuk kepatuhan dalam pengendalian pengobatan klien (Mairs et al., 2011).

\section{Metode Asesmen}

Sebelum melakukan asesmen dilakukan screening mengenai kondisi pasien terlebih dahulu. Screening digunakan untuk mengidentifikasi status mental dan kondisi mental klien. Selain itu screening juga berfungsi sebagai konfirmasi mengenai adanya gejala yang ada pada diri klien. Screening menggunakan WHO Disability Assessment Schedule (WHODAS) dimana pengisian dilakukan oleh pemeriksa dengan sumber dari observasi, wawancara dengan keluarga, ketua dan pengasuh di Yayasan Dian Atmajaya Lawang dan klien. Penggunaan WHODAS bertujuan untuk mengukur taraf keberfungsian akibat kondisi kesehatan mental yang dialami klien.

Setelah dilakukan screening, kemudian dilakukan asesmen untuk diagnosa dan penentuan intervensi dilakukan dengan serangkaian metode yang digunakan adalah observasi, wawancara, serta tes psikologi. Metode ini digunakan untuk menentukan diagnosa gangguan pada klien. Wawancara dilakukan untuk mendapatkan data tambahan secara mendalam berkaitan dengan riwayat perjalanan gangguan yang dialami oleh klien. Observasi juga dilakukan untuk mengetahui penampilan klien, perilaku, afek, gangguan perseptual, orientasi dan kesadaran klien.

Tes psikologis yang digunakan mencakup tes intelegensi dan kepribadian tes Weschler Adult Intelligence Scale (WAIS), grafis BAUM, Draw a person (DAP) dan House Tree Person (HTP), Sacks Sentence Completion Test (SSCT). Tes WAIS digunakan untuk mengetahui tingkat intelegensi klien dan beberapa gejala klinis yang dapat diungkapkan melalui tes WAIS. Tes grafis digunakan untuk mengetahui ciri kepribadian klien secara lebih mendalam dan komprehensif. Tes SSCT digunakan untuk mengetahui area konflik yang dialami oleh klien.

\section{Presentasi Kasus}

Klien laki-laki dewasa, berusia 24 tahun dan belum menikah. Klien merupakan pasien skizofrenia dengan onset gangguan sejak berumur 18 tahun, dan telah mengalami 4 kali kambuh semenjak dirawat di Yayasan Dian Atmajaya Lawang tahun 2015. Klien merupakan anak ke 4 dari 4 bersaudara, sejak klien berusia 4 tahun ayah kandungnya meninggal dunia dan ibunya sakit kanker payudara. Ketika ada orang meninggal dunia, keluarga menceritakan pada klien, bahwa pada saat ayahnya meninggal dunia klien digendong kakak perempuan berjalan dibawah keranda jenasah. Proses adat ini dilakukan agar yang ditinggalkan ikhlas menerima kepergiannya.

Pada waktu klien berusia 10 tahun, ibu klien menikah lagi. Ayah tirinya sangat sayang sekali pada klien dan memperlakukan klien dengan baik. Dikarenakan ayah tirinya terlalu baik, klien tidak berani mengatakan tidak atau membantah setiap keinginan dan keputusan ayah tirinya. Ayah tirinya juga tidak pernah marah, selalu mengarahkan klien, tetapi tidak pernah memberikan kesempatan pada klien, untuk menentukan apa yang sebenarnya klien inginkan. Urusan baju, sekolah juga semua kebutuhan klien ditentukan ayah tirinya. Klien tidak pernah diajari apapun sama ibu dan ayah tirinya, semua telah disediakan. Kalo klien pergi sebentar selalu dicari, akhirnya klien kurang mandiri, klien selalu bergantung pada ibu dan ayah tirinya. Ayah tirinya juga berpesan bahwa laki-laki tidak boleh menangis. Klien pada akhirnya menjadi pribadi penurut, selalu patuh pada orangtuanya. Bila klien ada masalah, klien menahan tangisnya, dikarenakan klien selalu teringat pesan bapak tirinya laki-laki harus kuat tidak boleh menangis.

Ketika klien duduk di kelas 2 SMK berusia 17 tahun, ibu kandungnya meninggal dunia dikarenakan sakit kanker payudara yang sudah cukup lama. Berselang 40 hari sepeninggal dunia ibu kandungnya, ayah tirinya mengalami kecelakaan dan seketika langsung meninggal dunia. Pihak sekolah memberitahu klien untuk segera pulang, dikarenakan ayah tirinya meninggal dunia. Klien sangat terpukul, pagi hari waktu klien akan berangkat ke sekolah, klien masih bertemu dengan ayah tirinya. Saat dalam perjalanan pulang ke rumah, klien dalam keadaan bingung dan juga tidak percaya, klien berharap semoga berita ini tidak benar. Sesampainya klien tiba di rumah para pelayat sudah banyak dan klien menjumpai ayah tirinya sudah meninggal dunia. Klien merasakan sedih sekali, sudah tiga kali klien merasa kehilangan keluarga yang sangat disayanginya dan klien harus melakukan proses adat yaitu berjalan dibawah keranda jenasah lagi. Berdasarkan hasil tes SSCT, klien terus menerus menyimpan perasaan bersalah tidak bisa menunggui ibunya ketika sakit sampai meninggal dunia. Penyesalan tersebut membuat klien terganggu dengan pemikirannya sendiri. Selain itu, klien mengalami ketakutan terhadap berita tentang kematian dan keranda jenasah yang berwarna hijau. Ketakutan tersebut membuat klien memaksa berperilaku untuk selalu menghindar.

Semenjak ibu dan ayah tirinya meninggal dunia, klien tinggal bersama dengan kakak perempuannya. Setelah lulus dari SMK, klien mengalami kebingungan menentukan pilihan bekerja atau melanjutkan kuliah. Klien belum pernah diajari bagaimana menyelesaikan permasalahan sendiri, selama ini klien selalu menerima apa yang diputuskan oleh orangtuanya. Untuk menyelesaikan kebingungannya, kakak perempuan memberi saran untuk 
meneruskan kuliah saja, karena klien mendapatkan beasiswa ikatan dinas di Jakarta. Sewaktu di Jakarta klien mengikuti ospek, mengalami masalah yang tidak pernah dibayangkan oleh klien.

Panitia menerapkan peraturan disiplin dan ketat, dimana klien harus bisa menyelesaikan tugas-tugas yang diberikan oleh panitia. Klien tidak bisa melaksanakan tugas ospek dengan baik, akhirnya klien sering kena marah dan hukuman dari panitia ospek. Klien dihukum tidak boleh makan tepat waktu, dan tidurnya harus di mushola. Berdasarkan tes WAIS, dengan IQ 82 klien masuk kategori dibawah rata-rata, sehingga dalam proses berfikir dan pengambilan keputusaan klien cenderung lamban dan membutuhkan arahan.

Klien merasa tertekan selama mengikuti ospek dan mempunyai pikiran negatif bahwa kakaknya telah menjerumuskan, menyengsarakan dan menipu dirinya. Klien menyampaikan amarahnya dengan menghubungi kakaknya berkali-kali setiap hari. Kakaknya merasa jenuh hampir setiap jam klien selalu menelpon, kakaknya akhirnya mengambil keputusan menjemput klien dan dibawa pulang. Hasil tes grafis menunjukkan bahwa klien mempunyai kepribadian yang tertutup, selalu menyalahkan dirinya sendiri, kurang memiliki kemampuan menyelesaikan masalah.

Setelah klien pulang ke rumah, klien tidak punya aktivitas yang berarti akhirnya klien berusaha mencari teman dengan teman yang nasibnya sama dengan klien. Dari pergaulan ini klien mulai mengenal minuman keras sampai ketempat prostitusi. Sewaktu ke prostitusi bersama teman-temannya klien dalam keadaan tidak sadarkan diri (mabuk). Setelah berhari-hari, klien menyadari perbuatannya ternyata salah, akhirnya klien selalu diliputi rasa bersalah, klien membayangkan perbuatannya sewaktu di prostitusi membuahkan seorang anak tetapi klien tidak bertanggung jawab. Ditambah lagi permasalah klien yaitu diputus teman dekatnya.

Cara mengatasi permasalahannya, klien meminum obat pusing dalam dosis tinggi, akhirnya klien mengalami sesak napas, klien merasa akan meninggal dunia. Klien dilarikan ke Rumah Sakit dan klien selamat. Setelah peristiwa itu, perilaku klien sering marah-marah, berkata kasar kepada kakaknya, bahkan terkadang klien sampai kesurupan. Klien sering duduk terpaku diam dengan tatapan kosong, tangan kaki dan seluruh badan bergetar seperti orang kedinginan, klien juga tersenyum sendiri, katanya sedang chat dengan mantan teman dekatnya. Bila klien disuruh mandi, klien akan mandi dengan memakai seluruh bajunya, juga bicara ngelantur tidak dapat dimengerti oleh orang lain. Perilaku lainnya klien selalu membawa pisau kemana-mana, kakaknya bertanya mengapa membawa pisau, klien menjawab buat jaga-jaga karena akan ada yang mencelakainya dirinya.

Sejak saat itu, klien dirawat di Yayasan Dian Atmajaya Lawang. Setelah klien dinyatakan sembuh, klien tidak diperbolehkan kemana-mana oleh kakaknya, klien hanya tinggal di dalam rumah, kakaknya menganggap bahwa klien itu sakit, takut lari dari rumah dan berkeliaran di jalan dan hilang. Kakak klien juga bercerita bahwa saudaranya ibu ada juga yang pernah di rawat di RSJ Menur dan saudara ibu banyak yang punya penyakit rasa takut, takut wudhunya tidak diterima, makanya kalo wudhu mau sholat selalu diulang-ulang katanya takut masih najis, nanti sholatnya tidak diterima.

Dinamika terbentuknya gangguan skizofrenia pada klien dapat dijelaskan melalui teori diathesis stres model yang menyatakan bahwa teori ini menggabungkan antara faktor biologis, psikologis, dan lingkungan yang berfokus pada interaksi antara predisposisi penyakit terhadap penyakit (Davidson et al., 2012; Nevid et al., 2005).

Dasar biologis untuk diathesis ini diketahui bahwa terdapat keturunan dari saudara kandung ibu yang pernah dirawat di RSJ Menur dan saudara ibu banyak yang mempunyai perilaku selalu was-was, bingung takut najis, wudunya selalu diulang-ulang, takut meninggal dunia, bila melihat orang meninggal dunia seperti dirinya mau meninggal dunia. Predisposisi genetik merupakan komponen penting dalam banyak psikpatologi termasuk skizofrenia (Davidson et al., 2012). Selain dasar biologis, diathesis bersumber dari karakteristik kepribadian. Kepribadian klien yang tertutup, menyalahkan diri sendiri dan kurangnya kemampuan menyelesaikan masalah sebagai respon coping dalam masalah dan stresor lingkungan yang dialaminya sehingga menyebabkan munculnya gangguan skizofrenia.

Klien mengalami 4 kali kambuh sejak tahun 2015, yaitu saat pertama kali dirawat di Yayasan Dian Atmajaya Lawang. Permasalahan klien saat ini adalah kurangnya menjalankan aktivitas sehari-hari di rumah dan di lingkungannya, setelah klien pulang menjalani perawatan dari Yayasan Dian Atmajaya Lawang. Klien merasa senang mengurung diri di dalam kamar dan tidak melakukan aktivitas apapun. Perasaan menyalahkan diri sendiri menyebabkan klien selalu memikirkan masalah yang sudah terjadi. Keengganan klien menghadapi masalahnya dan kurangnya keberfungsian di rumah dan lingkungannya menyebabkan klien manarik diri dari lingkungan. Kurangnya aktivitas atau kegiatan membuat klien mengalami relaps berkali-kali.

Klien tidak memiliki aktivitas harian yang bermanfaat untuk dilakukan dalam kehidupan sehari-harinya, setelah pulang perawatan dari Dian Atmajaya Lawang. Kurangnya kemampuan mengelola diri menyebabkaan klien mengembangkan perilaku hanya duduk terdiam dengan mata kosong, tidur-tiduran sepanjang hari, malas menjalankan aktivitas seperti merawat diri yang buruk tidak mandi dan tidak teratur dalam meminum obat, sering meninggalkan sholat dan malas melakukan aktivitas. Perilaku ini sebagai simptom negatif pada penderita skizofrenia dimana klien kehilangan kemauan untuk melakukan aktivitas (anhedonia) dan menarik diri dari lingkungannya. Berdasarkan tes WhoDas taraf keberfungsian klien dalam 30 hari terakhir, dengan angka rata-rata 3,2 yang artinya distress dalam kasus klien ini dikategorikan sedang. 
Cara mengatasi permasalahan perilaku pada klien, maka terapis menggunakan terapi aktivasi perilaku dengan memberikan aktivitas dan penjadwalan aktivitas, sebagai target intervensi. Aspek ini dirasa penting untuk menjaga kondisi kesehatan klien skizofrenia agar tidak mengalami relaps. Klien sendiri juga menginginkan dirinya sembuh dan tidak kembali ke Yayasan Dian Atmajaya Lawang. Intervensi yang dilakukan pun harus praktis dan konkrit karena keterbatasan intelektual klien.

Terapis menggunakan terapi aktivasi perilaku, terapi ini merupakan terapi perilaku yang bertujuan mendorong klien melakukan aktivitas tertentu yang menyenangkan dan memberikan rasa nyaman dengan mengupayakan reward untuk memperkuat perilaku yang diinginkan (Kanter et al., 2009). Intervensi bertujuan mengurangi perilaku maladaptive klien yaitu anhedonia, perilaku menarik diri dan hilangnya aktivitas yang menyenangkan. Perilaku anhedonia pada diri klien yaitu berdiam diri didalam rumah, dan tidak melakukan aktivitas apapun.

\section{Diagnosis dan Prognosis}

\section{Diagnosis}

Berdasarkan hasil asesmen dan uraian kasus di atas, Diagnostic and Statistical Manual of Mental Disorder Fifth Edition (DSM-5) (American Psychiatric Association, 2005), maka dapat ditegakkan diagnosis bahwa klien memenuhi kriteria diagnosis: Skizofrenia 295.90 (F20.9), dengan permasalahan kehilangan kesenangan melakukan aktivitas sehari-hari yang dulunya menyenangkan atau membuatnya bahagia (symptom anhedonia).

\section{Prognosis}

Prognosis memperkirakan keberhasilan klien dalam melakukan intervensi adalah baik. Dikarenakan klien memiliki komitmen ingin segera sembuh, klien merasa senang dengan adanya aktivitas yang akan diberikan. Klien juga memiliki keinginan yang kuat untuk tidak mengalami relaps dan tidak ingin kembali ke Yayasan Dian Atmajaya Lawang dimana klien sering dirawat. Dengan kapasitas yang klien miliki, klien mampu memahami intervensi yang diberikan dengan diberikan secara praktis dan konkrit. Keluarga sangat mendukung demi kesembuhan klien, selama ini klien hanya diberikan obat untuk mengatasi permasalahannya.

\section{Intervensi}

Metode intervensi yang akan dilakukan adalah terapi aktivasi perilaku. Terapi aktivasi perilaku mencakup pemantauan aktivitas, penjadwalan aktivitas yang diberikan dengan penguatan positive tetapi juga memperhatikan penguatan negatif untuk memperkuat kegiatan. Terapi aktivasi perilaku digunakan dalam mengatasi perilaku negatif dan membantu mengurangi simptom-simptom negatif pada skizofrenia dan efektif untuk kepatuhan dalam pengendalian pengobatan (Mairs et al., 2011).

Target intervensi pada aktivasi perilaku yang akan dilakukan adalah mengurangi perilaku maladaptive klien yaitu simptom anhedonia, perilaku kehilangan kesenangan melakukan aktivitas sehari-hari yang dulunya menyenangkan atau membuatnya bahagia. Perilaku anhedonia klien yaitu tidur-tiduran sepanjang hari, tidak melakukan aktivitas apapun. Prinsip aktivasi perilaku adalah shaping dan haping. Shaping dengan melibatkan respon dalam menyelesaikan kegiatan atau bentuk pekerjaan rumah, haping yaitu komitmen klien untuk melaksanakan kegiatan dan prinsip jalan bersama sesuai ketrampilan klien (Balán et al., 2016). Alasan dilakukan intervensi sesuai dengan masalah yang dialami klien terkait dengan kurangnya aktivitas dan kegiatan sehari-hari yang menyebabkan klien kambuh. Terapi dilakukan secara kongkrit dan disesuaikan dengan kemampuan klien. Dengan penjadwalan yang diberikan dan berlandaskan prinsip teori behavior, maka klien dapat langsung merubah perilaku dan menjalankan prosedur intervensi dengan konkrit.

Sebelum menetapkan terapi aktivasi perilaku pada klien, kakak-kakak klien diberikan penjelasan mengenai gangguan skizofrenia untuk meningkatkan kepedulian kepada klien dan berkomitmen untuk memberikan dukungan dalam hal perawatannya setelah keluar dari Yayasan Dian Atmajaya Lawang, serta mendorong dan memberikan klien tugas untuk membantu keluarga dalam melaksanakan pekerjaan rumah. Hal ini diperlukan untuk mendukung hasil intervensi dimana adanya keefektifan dan pengendalian dalam hal pengobatan dan perilaku yang akan dilakukan sehingga membutuhkan arahan dan dorongan dari orang terdekat. Informasi yang diberikan keluarga antara lain tentang gangguan skizofrenia secara umum, pentingnya konsumsi obat secara teratur, pentingnya aktivitas keseharian klien agar tidak berdiam diri didalam rumah dan merasa malas. Hal ini sebagai upaya agar keluarga mendukung klien melalui arahan dan pemberian dorongan dan dukungan serta reward pada klien apabila bisa melakukan kegiatan sehari-hari, sehingga adanya kontrol sebagai upaya mencegah relaps. Penguatan positif yang diberikan pada klien, berupa pemberian pujian kata hebat, setiap klien selesai melakukan aktivitas. Apabila klien menjalankan aktivitasnya selama 3 hari dengan baik, maka klien berhak meminta sesuatu yang diinginkan. Karena klien telah pulang dari rumah sakit, maka intervensi dilakukan di rumah klien dalam sembilan sesi, sebagai berikut:

Sesi I: Pengenalan terapi. Terapis menjelaskan diadakan terapi sebagai solusi atas permasalahan yang klien alami dan keluhkan. Serta menjelaskan prosedur yang akan diberikan pada klien dan manfaat terapi yang akan diberikan. Pada sesi ini klien memahami apa yang dijelaskan terapis dengan menganggukan kepala dan berkata akan mengikuti kata terapis. Klien mengatakan 
bahwa ingin segera sembuh, bisa bekerja dan rajin beribadah.

\section{Sesi II: Identifikasi kelemahan dan kelebihan diri dan tar-} get perubahan. Terapis bersama klien mengidentifikasi apa saja kelemahan klien dan apa saja kelebihan dalam diri klien. Setelah mengidentifikasi kelemahan dan kelebihan diri, klien diberikan arahan bagaimana memahami diri, sehingga kelebihan yang klien miliki dapat menunjangnya untuk kesembuhan. Setelah diketahui klien diminta untuk mengidentifikasi apa saja target perubahan yang harus dilakukan untuk menutupi kekurangan dan meningkatkan kelebihannya. Sesi ini berjalan cukup lancar, klien dapat mengidentifikasi apa saja kelemahan dan kekurangan dalam dirinya yang meliputi kurang rajin dan kurang semangat dalam menjalankan aktivitas, merasa minder dengan penyakit yang dideritanya. Klien menyadari bahwa klien mampu untuk bekerja dan merencanakan kegiatan agar dapat mendapatkan penghasilan.

Sesi III: Jadwal aktivitas untuk 1 hari kedepan. Klien dan terapis merancang jadwal aktivitas atau kegiatan yang akan dilakukan untuk esok hari dan disepakati bersama. Klien membuat jadwal apa saja kegiatan yang harus dilakukan setelah bangun tidur sampai tidur kembali. Instrumen yang digunakan adalah perencanaan aktivitas yaitu daftar kegiatan pagi, siang dan malam hari. Diawal sesi ini klien menyatakan bahwa dirinya minder akan penyakit yang dideritanya. Saat didorong bahwa dengan klien rajin melakukan aktivitas akan sembuh, klien bersemangat untuk tidak kembali ke Yayasan Dian Atmajaya Lawang, dimana klien dirawat. Klien segera membuat jadwal kegiatan untuk esok hari yang meliputi bangun pagi, membersihkan tempat tidur, mandi serta makan pagi dan minum obat, membantu kakak membersihkan rumah, dan sholat tepat waktu.

Sesi IV: Monitoring aktivitas. Terapis memastikan, apakah kemarin klien telah melaksanakan aktivitas yang telah dijadwalkan dan telah disepakati. Terapis memastikan bagaimana ketercapaian aktivitas sebelumnya dengan menanyakan pada kakak klien terkait dengan apa yang telah klien laksanakan hari kemarin. Terapis dan klien memberikan centang apa saja yang telah klien lakukan di hari sebelumnya di kertas jadwal kegiatan. Terapis mendorong klien dengan memberikan sugesti pada klien untuk melaksanakan aktivitas secara rutin, klien dapat sembuh dan mendorong klien untuk berinteraksi dengan orang lain. Sesi ini berjalan lancar, klien dengan cepat menjelaskan apa saja kegiatan yang telah klien lakukan dalam sehari kemarin. Klien menceritakan bahwa klien bangun kesiangan, namun klien tetap membersihkan tempat tidur dan mandi pagi serta minum obat. Selanjutnya klien membantu kakaknya membersihkan rumah. Di siang hari klien sholat di mushola di dekat rumahnya, yang dilanjutkan makan siang dan istirahat sambil menonton televisi. Dimalam harinya klien melakukan sholat, makan malam dan melanjutkan tidur untuk beristirahat. Diakhir sesi klien menyadari bahwa klien masih bermalasmalasan, namun setelah diberikan dorongan kembali klien menyatakan bahwa klien akan berusaha dan tetap melaksanakan aktivitas atau kegiatan sehari-hari.

Sesi V: Jadwal aktivitas untuk sehari-hari. Terapis dan klien mengidentifikasi kegiatan apa saja, yang akan dilakukan klien selama 1 minggu dan itu akan klien praktekkan dalam kegiatan sehari-hari. Pada sesi ini terapis dan klien membuat jadwal kegiatan selama 1 minggu yang meliputi kegiatan di pagi hari, seperti bangun dan membersihkan tempat tidur, sholat, makan pagi dan minum obat, melakukan aktivitas di pagi hari meliputi olah raga, mengambil air, membersihkan rumah, mencuci baju, dan membantu kakak di dapur. Kegiatan di siang dan sore hari meliputi sholat dhuhur di mushola depan rumah, makan siang serta istirahat dengan menonton televisi, mandi di sore hari dan sholat ashar, aktivitas di sore hari yang dilakukan klien jalan-jalan berkeliling sekitar rumah. Aktivitas di malam hari melakukan sholat maghrib dan isyak makan malam dan minum obat, melakukan aktivitas di malam hari dengan membaca al-quran.

Sesi VI: Psikoedukasi keluarga. Terapis menjelaskan kembali pada kakaknya, tentang bagaimana penjelasan tentang gangguan skizofrenia. Mendorong kakaknya, untuk tetap memberikan dukungan kepada klien dengan mengontrol klien untuk melakukan aktivitas-aktivitas. Mengajak klien untuk melakukan aktivitas bersama membantu kakak di dapur, dan sholat 5 waktu di mushola agar klien memiliki aktivitas-aktivitas demi kesembuhaan klien. Kakaknya didorong untuk memberikan reward kepada klien dengan memasak kesukaan makanan klien. Pada sesi ini, kakaknya memahami apa yang dijelaskan terapis dan kakaknya akan berusaha memberikan dukungan untuk kesembuhan klien. Kakaknya akan berusaha mengecek kegiatan klien dan mengingatkan klien untuk selalu melakukan aktivitasnya. Di akhir sesi kakaknya menjelaskan apabila klien rajin melakukan aktivitas dan tidak bermalas-malasan, serta membantu kakaknya maka kakaknya akan memasakan makanan favorit klien atau yang diinginkan klien.

Sesi VII: Monitoring aktivitas. Terapis memastikan kembali apakah selama 4 hari sebelumnya melaksanakan aktivitas, sesuai apa yang telah dijadwalkan dan disepakati. Terapis memastikan ketercapaian aktivitas sebelumnya dengan menanyakan pada kakaknya terkait dengan apa yang telah klien laksanakan. Terapis mengecek dengan mencentang apa saja yang telah klien lakukan dengan mengkonfirmasi bersama kakaknya. Pada sesi ini saat terapis datang, klien menyapa terapis langsung berkata bahwa dirinya belum melakukan sholat ashar dan ijin keluar untuk sholat di mushola. Setelah klien selesai sholat, klien dan terapis mencheklist kegiatan yang telah klien lakukan yang didampingi kakaknya untuk mengkonfirmasi kegiatannya. Klien dengan cepat menjelaskan hasil kegiatan yang dilakukannya setiap harinya dan semakin 
meningkat. Klien merasa senang dengan apa yang klien lakukan dan telah dijadwalkan.

Sesi VIII: Evaluasi dan terminasi. Terapis melakukan evaluasi terhadap tugas dan aktivitas yang telah dilakukan klien pada sesi ke depan. Setelah itu terapis menyimpulkan hal-hal yang telah dipelajari klien selama proses intervensi dengan memberikan bekal agar klien mau membiasakan diri untuk melakukan aktivitas dengan jadwal yang telah ditempel didinding rumah. Terapis meminta pada kakaknya untuk tetap mengontrol klien meskipun proses intervensi telah selesai. Sesi ini mengevaluasi hasil yang didapat dan klien mendengarkan arahan terapis. Klien mengatakan bahwa mulai hari ini dan selanjutnya akan tetap melaksanakan aktivitas dan tidak bermalas-malasan di rumah agar penyakitnya tidak kambuh.

Sesi IX: Follow up. Melihat perubahan dan perkembangan pada klien pasca intervensi dengan melakukan wawancara terhadap klien dan kakaknya. Tiga minggu pasca intervensi berakhir terapis kembali melakukan wawancara pada kakaknya terkait perubahan klien, kakaknya mengataaan bahwa klien telah melakukan aktivitas sesuai dengan jadwal yang dibuat. Klien melakukan kegiatan yang telah disepakati meliputi mandi dua kali sehari, tepat waktu dalam meminum obat, pergi kemushola melakukan sholat dan membantu kakak mengerjakan pekerjaan rumah. Klien saat ini juga mempunyai aktivitas baru bekerja di pabrik kasur dekat rumah.

\section{Hasil dan Pembahasan}

\section{Hasil}

Hasil intervensi yang dilakukan, terpenuhi dengan meningkatnya aktivitas yang dilakukan klien pada setiap harinya. Hasil peningkatan aktivitas harian yang dilakukan, dalam data checklist kegiatan dengan total kegiatan 16, klien mampu memenuhi target sebanyak 12 kegiatan. Dengan berbagai macam aktivitas yang dilakukan berbeda disetiap harinya. Seperti olahraga, mengambil air, membersihkan rumah, mencuci baju dan membantu kakak di dapur. Hasil optimal apabila klien melaksanakan 16 aktivitas dalam sehari dari bangun tidur sampai tidur kembali. Hal ini pun tidak mudah bagi klien yang sebelumnya memiliki perilaku yang maladaptif dengan tidak mandi, hanya bermalas-malasan dan tidak melakukan aktivitas untuk keluar rumah sekalipun. Oleh karena itu, peningkatan secara bertahap dilakukan dalam proses dengan mengkonfirmasi pada kakak klien sebagai kemajuan dari proses intervensi yang dilakukan. Jumlah aktivitas selama intervensi dapat dilihat pada Gambar 1.

Total kegiatan yang dilakukan klien menunjukkan perubahan, dan kemajuan selama tahap monitoring aktivitas keseharian. Sebelumnya intervensi dilakukan klien cenderung tidak melakukan aktivitas hanya bermalasmalasan, dengan sering berkata capek dan merebahkan badannya diatas kasur sampai jam makan siang. Perubahan

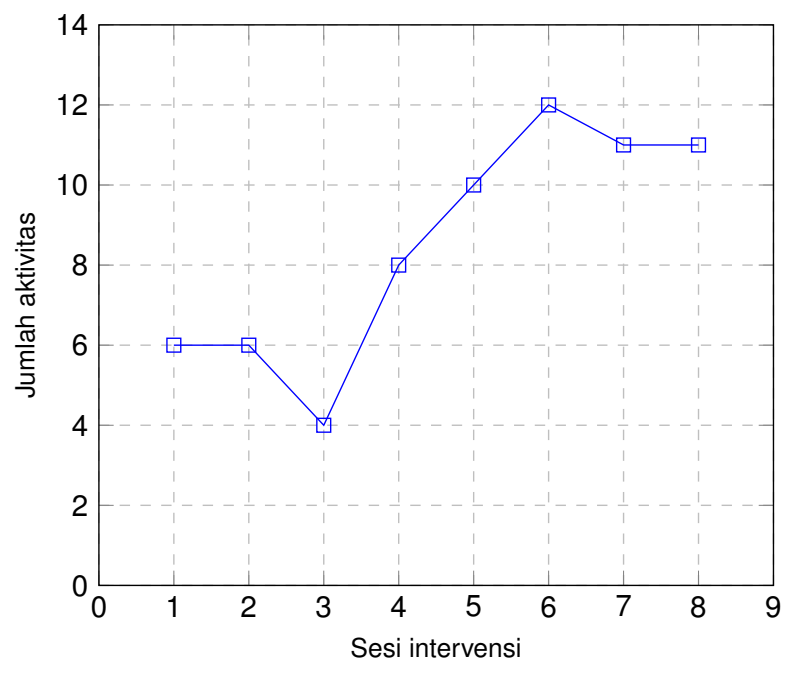

Gambar 1. Perkembangan jumlah aktivitas klien dilihat dari sesi ke sesi, termasuk sesi terakhir (sesi ke-8) adalah sesi follow-up.

perilaku maladaptif menjadi perilaku yang adaptif diawali ketika sesi ke 5 di hari ke 3 proses intervensi berlangsung. Klien menyatakan bahwa hari sebelumnya klien mandi di pagi hari, meskipun di sore harinya klien tidak mandi. Selanjutnya klien menyatakan bahwa klien tidak membantu kakaknya, hanya diam di rumah melihat televisi dan hanya sholat dhuhur di mushola dan tidak merapikan tempat tidur.

Pada follow up, kakaknya melaporkan bahwa klien tetap melakukan aktivitas sesuai dengan jadwal yang dibuat, tetapi klien belum mampu melakukan aktivitas penuh yaitu 16 kegiatan setiap harinya. Kakak dan seluruh keluarga juga tetangga, mendukung klien melaksanakan kegiatan sesuai jadwal terutama mandi, makan dan minum obat teratur dan sholat di mushola dan mengasih penghargaan berupa pujian kepada klien.

\section{Pembahasan}

Terapi aktivasi perilaku sebagai salah satu terapi yang menunjukkan hasil yang unggul dalam beberapa kondisi dalam pengobatan penyakit medis (Balán et al., 2016). Hasil dari penelitian sesuai dengan terapi yang diberikan kepada klien, aktivasi perilaku yang dilakukan menunjukkan hasil yang sesuai target dengan meningkatnya aktivitas keseharian yang dilakukan klien. Meningkatnya jumlah aktivitas diartikan bahwa klien dapat dengan mampu dan mau menjalankan aktivitas dengan jadwal yang ditempel dikamar klien dan didorong oleh kakaknya. Aktivitas yang dipilih merupakan aktivitas positif pilihan klien, yang membuat klien merasa nyaman dan menyenangkan. Sesuai dengan teknik aktivasi perilaku bahwa klien diajak menentukan sendiri, kegiatan positif apa yang dilakukan sehari-hari seperti mandi, sholat, membersihkaan rumah. 
Prinsip aktivasi perilaku adalah shaping dan haping terpenuhi. Shaping dengan melibatkan respon dalam menyelesaikan kegiatan atau bentuk pekerjaan rumah, dimana klien diberikan berbagai macam aktivitas yang disesuaikan dengan keinginan dan kemampuan klien. Aktivitas yang diberikan berkaca pada kepribadian dan intelegensi klien. Shaping yang dilakukan konkrit, praktis dan mudah akan memberikan dampak yang baik secara berkala. Haping yang dilakukan dikuatkan dengan komitmen klien dan keinginannya untuk sembuh dan tidak ingin kembali ke Yayasan Dian Atmajaya Lawang, sehinga klien didorong untuk melakukan komitmen yang tinggi untuk menjalankan aktivitas dan tidak bermalas-malasan.

Kedua prinsip yang saling dikuatkan tentunya akan dapat meningkatkan aktivitas klien dan gejala anhedonia klien. simptom negatif anhedonia yang berkembang pada klien, berdampak pada kurangnya aktivitas seharihari ditandai dengan motivasi yang kurang akan minat melakukan sesuatu yang menyenangkan, sehingga pasien dengan skizofrenia cenderung berkurangnya perawatan dan kebersihan diri, kurangnya terlibat dalam pekerjaan, dan kurangnya keterlibatan sosial (Trémeau, 2012; Messinger et al., 2011).

Struktur dan jadwal kegiatan yang dilakukan klien adalah mengikuti sesuai rencana dan bukan pemaksaan. Dengan adanya penjadwalan aktivitas dan monitoring kegiatan klien, klien didorong untuk melakukan aktivitas yang telah dijadwalkan dan sesuai rencana yang telah disepakati. Meskipun tidak semua aktivitas dilakukan klien secara terus menerus, namun klien telah mengembangkaan perawatan dirinya dengan makan dan minum obat tepat waktu, sholat 5 waktu, dan kebersihan diri yang masih harus terus didorong serta berinteraksi dengan lingkuangan sekitarnya.

Peran keluarga yaitu kakak dalam memberikan arahan kepada klien menjadi salah satu faktor penting dalam program ini. Kakak terlibat dan memiliki peran penting dalam meningkatkan hasil program intervensi dengan mendorong klien untuk beraktivitas dan mengajak klien melakukan aktivitas bersama-sama, selain itu reward kepada klien diberikan oleh kakaknya sehingga terjalin hubungan dengan baik antara kakak dan klien. Pemberian informasi kepada keluarga dilakukan karena keluarga sebagai system pendukung yang utama dan memiliki peran yang penting dalam mencegah terjadi kekambuhan pada pasien skizofrenia (Davidson et al., 2012).

\section{Kesimpulan dan Saran}

Terapi aktivasi perilaku dapat berperan dalam membantu pasien skizofrenia untuk mengurangi simptom anhedonia dengan memberikan jadwal aktivitas harian. Aktivitas harian klien meningkat dengan jadwal kegiatan yang telah disepakati. Peran kakak dalam keluarga dapat memberikan supervisi, arahan dan dukungan untuk mendukung keberhasilan klien dalam intervensi. Selain itu, penetapan target yang konkrit dan realistis sesuai dengan kondisi klien. Melalui terapi aktivasi perilaku, klien diharapkan dapat menjalankan aktivitasnya seharihari secara lebih produktif dan mengurangi kerentanan terhadap relaps.

\section{Referensi}

American Psychiatric Association. (2005). Diagnostic and statistical manual of mental disorders fourth edition text revision. American Psychiatric Association.

Ansah, A, O., Panyin, A, B., Obirikorang, C., Agyare, C., Acheampong, E., Kwofie, E.N. (2018). Metabolic syndrome among schizophrenic patients: A comparative cross-sectional study in the middle belt of Ghana. Schizophrenia Research and Treatmen, 18(9), 1-9. https://doi.org/10.1155/2018/ 6542983

Balán, I. C., Lejuez, C. W., Hoffer, M., \& Blanco, C. (2016). Integrating motivational interviewing and brief behavior activation therapy : Theoretical and practical considerations. Cognitive and Behavior Practice, 23(2), 205-220. https://doi. org/10.1016/j.cbpra.2015.07.001

Cuijpers, P., van Straten, A., \& Warmerdam, L. (2007). Behavior activation treatments of depression: A metaanalysis. Clinical Psychology Review, 27(3), 318-326. https: //doi.org/10.1016/j.cpr.2006.11.001

Davidson, G.C., Neale, J.M., \& Kring, A.M. (2012). Psikologi Abnormal Edisi ke-9. PT Raja Grafindo Persada

Hopko, D. R., Magidson, J. F., \& Lejuez, C. W. (2011). Treatment failure in behavior therapy : focus on behavior activation for depression. Journal of Clinical Psychology, 67(11), 1106-1116. https://doi.org/10.1002/jclp.20840

Kanter, J., Busch, A. M., \& Rusch, L. C. (2009). Behavior activation: distinctive features. Routledge.

Mairs, H., Lovell, K., Campbell, M., \& Keeley, P. (2011). Development and pilot investigation of behavior activation for negative symptoms. Behavior Modification, 35(5), 486-506. https://doi.org/10.1177/0145445511411706

Messinger, J. W., Trémeau, F., Antonius, D., Mendelsohn, E., Prudent, V., Stanford, A. D., \& Malaspina, D. (2011). Avolition and expressive deficits capture negative symptom phenomenology: implications for DSM-5 and schizophrenia research.Clinical psychology review, 31(1), 161-168. https: //doi.org/10.1016/j.cpr.2010.09.002

Nevid, J.S., Rathus, S.A. \& Greene, B. (2005). Psikologi Abnormal, Edisi kelima, Jilid 2. Penerbit Erlangga

Oltmanns, T.F., \& Emery, R.E. (2013). Psikologi Abnormal. Pustaka pelajar.

Scholten, M., Vanhonk, J., Aleman, A., \& Kahn, R. (2006). Behavior inhibition system(BIS), Behavior activation system (BAS) and schizophrenia: Relationship with psychopathology and physiology. Journal of Psychiatric Research, 40(7), 638-645. https://doi.org/10.1016/j.jpsychires.2006.03.005

Trémeau, F., Nolan, K. A., Malaspina, D., \& Javitt, D. C. (2012). Behavior validation of avolition in schizophrenia. Schizophreni research, 138(2), 255-261. https://doi.org/10. 1016/j.schres.2012.02.018 